\title{
Influence of Bee Pollen on the Bioactive Behavior, Sensory and Physicochemical Properties of White Cheese Made from Camel and Cow Milk Mixture Abeer M. Abd Elhamid ${ }^{1}$ and Mervet M. Elbayoumi ${ }^{2}$ \\ ${ }^{1}$ Department of Food and Dairy Science \&Technology, Faculty of Agriculture, Damanhour University, Damanhour, 22516, Egypt. \\ ${ }^{2}$ Breeding of Animal and Poultry Department, Desert Research Center, Cairo, Egypt.
}

\section{ABSTRACT}

The research aims to improve the therapeutic effect of white cheese by studying the effects of addition bee pollen on the bioactive behavior, sensory and physicochemical properties. Results indicated that bee pollen increased the antioxidant activities of the white cheese. The phenolic components in the bee pollen indicated good potential to inhibit the growth of $E$. coli (ACCT 8739), St. aureus (ATCC 6538) and S. typhimurium (ACCT 25566). Yield, total solid, fat and protein content of white cheese increased with the addition of bee pollen. No significant effects were observed on the sensory properties, compared with the control up to $1 \%(\mathrm{w} / \mathrm{v})$. The addition of bee pollen during the production of white cheese is found to be necessary to increase the bioactive activities of the resultant cheese.

Keywords: bee pollen, polyphenols, physicochemical and sensory attributes, white cheese.

\section{INTRODUCTION}

The bee pollen has been collected by honey bees was used for human nutrition as a "perfect health food" after the Second World War (Bogdanov 2012). German Federal Board of Health, (Linskens and Jorde, 1997) recognized pollen as a medicine, because it contains bioactive components, which enhance health through the interactions of food matrix and nutrients in maintaining human biological processes (Saura-Calixto, F. 2011), such as proteins, carbohydrates, lipids, amino acids, minerals, vitamins (namely $\mathrm{C}, \mathrm{E}, \beta$ carotene, B-complex), trace elements and polyphenols (Malerbo-Souza, 2011 and de Arruda et al., 2013). The main bioactive components of bee pollen are the polyphenols, mostly flavonoids. The main bioactive flavonoids are isorhamnetin3-O-rutinoside, quercetin3-Orutinoside, naringenin, rhamnetin3- $O$-neohesperidoside, quercetin3-O-neohesperidoside, isorhamnetin, quercetin, kaempferol (Han, et al., 2012). Polyphenols possess diverse biological properties such as antiaging, anticarcinogen, antioxidant, antiinflammatory, cardioprotective and antiatherosclerosis, so the interest in the importance of polyphenols on human health has been growing (Han, et al., 2007).

Recently, cheese production containing nutritionally important amounts of polyphenols has increased because; cheese contains a small amount of polyphenols (O'Connell and Fox, 2001). Only a few researches have been proposed on the effects of phenolic compounds in rennet curds (Han, et al., 2011a and Han, et al., 2011b).Several researches aimed to improve the healthy effect of cheese, such as addition of the catechin to low-fat hard cheese (Rashidinejad et al., 2013). Sharma et al., (2011) produced a novel cheese with blending dried broccoli sprouts powder, and Giroux et al., (2013) in making Cheddar cheese enrichment with green tea polyphenols.

Camel milk is gaining increasing recognition due to it beneficial effects in the control and prevention of multiple health problems. Recent studies have shown that camel milk has anti-hypertensive, anti-carcinogenic, hepatoprotective, hypocholesterolemic effects as well as anti- diabetic and antioxidative factors (Majeed 2005; Elayan et al., 2008 and Khan and Alzohairy 2011 Abd Elhamid and Elbayoumi 2017), however, Mehaia and Qassim, (1993) indicated that the coagulum obtained from camel milk was very soft as compared to that of cow milk and took very long time, and he found that making the cheese from the mixture of camel milk and cow milk improved the coagulation process

The objective of this study was to examine the effect of the incorporation of bee pollen on the bioactive activities, sensory attributes and physicochemical properties of White cheese made from camel and cow milk mixture.

\section{MATERIALS AND METHODS}

Samples of bee pollen were collected from a commercial apiary located in Damanhour district, El-Behera governorate, Egypt. The collected pollen was dried at $<40{ }^{\circ} \mathrm{C}$ for $20 \mathrm{hrs}$. The dried pollen was grind and sieved through a $37 \mu \mathrm{m}$ mesh, and stored in a freezer at $-15^{\circ} \mathrm{C}$ throughout the study.

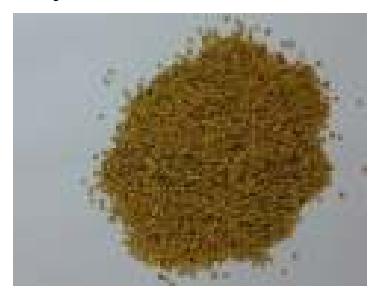

(a)

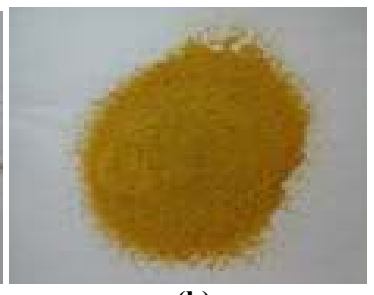

(b)
Figure 1. bee pollen (a): before grinding (b): after grinding

HPLC analysis was carried out using Agilent Technologies 1100 series liquid chromatograph equipped with an auto sampler and a diode-array detector. The analytical column was a Eclipse XDB-C18 (150 X $4.6 \mu \mathrm{m}$; $5 \mu \mathrm{m}$ ) with a C18 guard column (Phenomenex, Torrance, CA). The mobile phase consisted of acetonitrile (solvent A) and $2 \%$ acetic acid in water (v/v) (solvent B). The flow rate was kept at $0.8 \mathrm{ml} / \mathrm{min}$ for a total run time of $70 \mathrm{~min}$ and the gradient programme was performed according to Oszmiansky, et al., (1988)

Cheese making was carried out by the method described by Abou-Donia (2008). Camel milk (0.25\%) and fresh cow's milk $(0.75 \%)$ were mixed. the mixture of milk was divided into five parts $(5 \mathrm{~kg})$, which were mixed with $0 \%, 0.5 \%, 1 \%, 1.5 \%$ and $2 \%(\mathrm{w} / \mathrm{v})$ of bee pollen. Sodium chloride was added $(3 \% \mathrm{w} / \mathrm{w})$. Pasteurisation was carried out at $63^{\circ} \mathrm{C}$ for $30 \mathrm{~min}$ and then cooled to $42{ }^{\circ} \mathrm{C}$, calcium chloride was added $(0.02 \% \mathrm{WN})$. Then inoculated with $2 \%$ of mixed (1:1) Lb del ssp. bulgaricus (Lb), and $S$. thermophilus (ST). Calf rennet was added to coagulate milk within 2-3 h. The curds were separately transferred into wooden frames and left $24 \mathrm{~h}$ for wheying off. The cheese 
curd was cut into cubes (Figure 2), pickled in its whey (3\% $\mathrm{w} / \mathrm{w}$ salt), and stored for repining at refrigerated temperature $\left(10^{\circ} \mathrm{C}\right)$ for 45 days. Three replicates of experimental cheeses were processed for bee pollen mixtures.

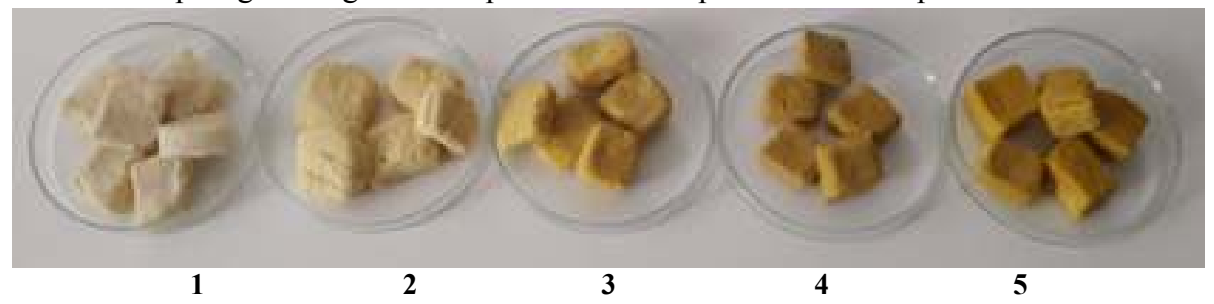

Figure 2. White cheese from camel and cow milk mixture with added bee pollen: 1, control without bee pollen; 2 , white cheese with 0.5 g bee pollen / 100 ml milk; 3, white cheese with $1 \mathrm{~g}$ bee pollen / $100 \mathrm{ml}$ milk; 4, white cheese with $1.5 \mathrm{~g}$ bee pollen / $100 \mathrm{ml}$ milk; 5 , white cheese with $2 \mathrm{~g}$ bee pollen / $100 \mathrm{ml}$ milk.

Bioactive Activities Analysis was examined by measuring the total phenolic content by the Folin-Ciocalteu method (Singleton, et al., 1999). For measuring the inhibition of ascorbate autoxidation, the method of Oyaizu (1986) was used, while reducing power assay was measured according to Zhu, et al., (2008).

Antibacterial activity test of the following strains: Lb del ssp. bulgaricus (EMCC 1102), and $S$. thermophilus (EMCC 1102), St. aureus (ATCC 6538), B. cereus (ATCC 9639), S. typhimurium (ACCT 25566) and $E$. coli (ACCT 8739), were used in the assay protocol (Collins, et al., 1995)

$\mathrm{pH}$ value of samples were determined using a digital $\mathrm{pH}$ meter as given by AOAC (2000), total solids contents were measured by the method of Marshall (1992), while the yield was calculated according to Sipahioglu et al. (1999). The total nitrogen- protein was measured using the Kjeldahl method (AOAC, 2000). Salt was determined using the method of Volhard (Jame 1995); and the fat according to AOAC (2000). All the above mentioned measurements were carried out in triplicate. The sensory evaluation of cheese treatments were evaluated according to Bodyfelt et al. (1988). Data were statistically analyzed using the statistical analysis system software package (SAS 2000). Analyses of variance were performed using ANOVA procedures. Standard error was obtained from the statistical model.

\section{RESULTS AND DISCUSSION}

Data of phenolic compounds by (HPLC) in bee pollen are shown in Table (1). Quercetin $(251.21 \mu \mathrm{g} / \mathrm{g})$ was the major phenolic compounds detected in the samples with added of bee pollen, followed by the Ferulic $(246.80 \mu \mathrm{g} / \mathrm{g})$. Similar result was obtained by Serra Bonvehí et al. (2001), who found that the predominant flavonoids was the quercetin (Bonvehí, et al.,2001). Bee pollen is also rich in $p$-coumaric $(67.08 \mu \mathrm{g} / \mathrm{g})$, Kaempferol $(49.22 \mu \mathrm{g} / \mathrm{g})$, Chrysin $(25.14 \mu \mathrm{g} / \mathrm{g})$, Rutin $(22.33 \mu \mathrm{g} / \mathrm{g})$ and Sinapic $(20.67 \mu \mathrm{g} / \mathrm{g})$. Chlorogenic and Caffeic were present in very small amounts in bee pollen. These results were in agreement with Lundgren and Wiedenmann (2004) and Žilić et al., (2014).

For measuring the activity of antioxidant, results in Table (2) show that the total phenols increased from 11.53 to $46.12 \mathrm{mg} / \mathrm{g}$ cheese as the level of bee pollen increased from 0.5 to $2 \%$ at zero time. The inhibition of ascorbate content increased from 1303 to $5261 \mu \mathrm{g} / \mathrm{g}$ cheese. Similar observations were observed by Najgebauer-Lejko et al., (2011) and Rashidinejad et al., (2013). Inhibition of ascorbate content increased significantly at the end of ripening period. This might be attributed to the presence of tyrosine residues, proteins or sugar components from lactose and oligosaccharide, being present in the cheeses (Singleton, et al., 1999). Reducing power assay (\%inhibition) increased from 33.61 to $98.37 \%$ cheese as the level of bee pollen increased from 0.5 to $2 \%$ at zero time. This result agreed with Rashidinejad et al., (2013).

Table 1. Analysis of phenolic compounds by highperformance liquid chromatography (HPLC) in pollen bee.

\begin{tabular}{lccc}
\hline Compound & $\begin{array}{c}\text { Conc. } \\
(\boldsymbol{\mu g} / \mathbf{g})\end{array}$ & Compound & $\begin{array}{c}\text { Conc. } \\
(\boldsymbol{\mu g} / \mathbf{g})\end{array}$ \\
\hline Pyrogallol & ND & Rutin & 22.33 \\
Gallic & ND & p-coumaric & 67.08 \\
Protocatechuic & ND & Naringin & ND \\
$p$-hydroxybenzoic & 14.85 & Hesperidin & ND \\
Gentisic & ND & Apigenin-7-glucoside & ND \\
Cateachin & ND & Myricetin & ND \\
Chlorogenic & 6.22 & Rosmarinic & ND \\
Caffeic & 11.86 & Cinnamic & ND \\
Syringic & ND & Quercetin & 251.21 \\
Vanillic & ND & Apigenin & ND \\
Scopoletin & 3.01 & Kaempferol & 49.22 \\
Ferulic & 246.80 & Chrysin & 25.14 \\
Sinapic & 20.67 & & \\
\hline
\end{tabular}

Table 2. Changes of total phenols content, inhibition of ascorbate and reducing power assay (\%inhibition) contents in white cheeses from camel and cow milk mixture as affected by different bee pollen during repining storage.

\begin{tabular}{|c|c|c|c|c|}
\hline Treatments & $\begin{array}{l}\text { Storage } \\
\text { period } \\
\text { (days) }\end{array}$ & $\begin{array}{c}\text { Total } \\
\text { phenols } \\
\text { (mg/g } \\
\text { cheese) }\end{array}$ & $\begin{array}{c}\text { Inhibition } \\
\text { of ascorbate } \\
\mu \mathrm{g} / \mathrm{g} \\
\text { cheese) }\end{array}$ & $\begin{array}{c}\text { reducing } \\
\text { power } \\
\text { assay (\% } \\
\text { inhibition) }\end{array}$ \\
\hline \multirow{4}{*}{$\begin{array}{l}\text { Control } \\
\text { cheese }\end{array}$} & 0 & $1.44^{\mathrm{e}}$ & $139^{1}$ & $3.61^{\mathrm{j}}$ \\
\hline & 15 & $1.46^{\mathrm{e}}$ & $113^{\mathrm{s}}$ & $3.40^{\mathrm{j}}$ \\
\hline & 30 & $1.49^{\mathrm{e}}$ & $100^{\mathrm{r}}$ & $3.22^{\mathrm{j}}$ \\
\hline & 45 & $1.51^{\mathrm{e}}$ & $92^{\mathrm{q}}$ & $3.10^{\mathrm{j}}$ \\
\hline \multirow{4}{*}{$\begin{array}{l}\text { Cheese with } \\
0.5 \% \text { bee } \\
\text { pollen }\end{array}$} & 0 & $11.53^{\mathrm{d}}$ & $1303^{\mathrm{P}}$ & $33.61^{\mathrm{h}}$. \\
\hline & 15 & $11.76^{\mathrm{d}}$ & $1297^{\circ}$ & $32.72^{\text {hi }}$ \\
\hline & 30 & $12.00^{\mathrm{d}}$ & $1213^{\mathrm{n}}$ & $31.93^{\mathrm{hi}}$ \\
\hline & 45 & $12.18^{\mathrm{d}}$ & $1157^{\mathrm{m}}$ & $30.83^{\mathrm{i}}$ \\
\hline \multirow{4}{*}{$\begin{array}{l}\text { Cheese with } \\
1 \% \text { bee } \\
\text { pollen }\end{array}$} & 0 & $23.05^{\mathrm{c}}$ & $2990^{1}$ & $46.53^{t}$ \\
\hline & 15 & $23.45^{\mathrm{c}}$ & $2802^{\mathrm{k}}$ & $45.37^{\mathrm{f}}$ \\
\hline & 30 & $23.74^{\mathrm{c}}$ & $2660^{j}$ & $44.13^{\mathrm{f}}$ \\
\hline & 45 & $23.94^{\mathrm{c}}$ & $2501^{\mathrm{i}}$ & $42.26^{\mathrm{g}}$ \\
\hline \multirow{4}{*}{$\begin{array}{l}\text { Cheese with } \\
1.5 \% \text { bee } \\
\text { pollen }\end{array}$} & 0 & $34.59^{\mathrm{b}}$ & $3172^{\mathrm{n}}$ & $76.75^{\mathrm{c}}$ \\
\hline & 15 & $35.03^{\mathrm{b}}$ & $3131^{\mathrm{g}}$ & $75.36^{\mathrm{cd}}$ \\
\hline & 30 & $35.36^{\mathrm{b}}$ & $3097^{\mathrm{f}}$ & $73.34^{\text {de }}$ \\
\hline & 45 & $35.68^{\mathrm{b}}$ & $3041^{\mathrm{e}}$ & $72.79^{\mathrm{e}}$ \\
\hline \multirow{4}{*}{$\begin{array}{l}\text { Cheese with } \\
2 \% \text { bee } \\
\text { pollen }\end{array}$} & 0 & $46.12^{\mathrm{a}}$ & $5261^{d}$ & $98.37^{\mathrm{a}}$ \\
\hline & 15 & $46.78^{\mathrm{a}}$ & $5117^{\mathrm{c}}$ & $97.21^{\mathrm{ab}}$ \\
\hline & 30 & $46.33^{\mathrm{a}}$ & $5097^{b}$ & $96.50^{\mathrm{ab}}$ \\
\hline & 45 & $46.65^{\mathrm{a}}$ & $5071^{\mathrm{a}}$ & $95.43^{b}$ \\
\hline
\end{tabular}

*Means of triplicates. Means followed by the same superscript are not significantly different, $\mathrm{P}<\mathbf{0 . 0 5}$. 
Results in Table (3) indicate that there was no antibacterial effect on the $L b$. del. ssp. bulgaricus (EMCC 1102 ) and $S$. thermophilus (EMCC 1102) up to $2 \%$ bee pollen, while in the case of St. aureus (ATCC 6538), the inhibition zones were $0.2,0.4,0.6$ and $0.8 \mathrm{~cm}$ at $0.5,1,1.5$ and $2 \%$ bee pollen ,respectively. Bee pollen showed no effect on B. cereus (ATCC 9639), which agreed with Erkmen and özcan (2008) and Yerlikaya (2014) at $2.5 \%$ $(\mathrm{v} / \mathrm{v})$. The highest antibacterial activity was obtained with $2 \%$ bee pollen with a 1 and $1.2 \mathrm{~cm}$ zone of inhibition of $S$. typhimurium (ACCT 25566) and E. coli (ACCT 8739), respectively. Similar results were obtained by Yerlikaya (2014). This might be attributed to the presence of quercetin and other phenolic compounds in bee pollen, which are of antibacterial effect.

Table 3. Antibacterial activity (zone of inhibition: cm) of bee pollen.

\begin{tabular}{|c|c|c|c|c|c|}
\hline \multirow[b]{2}{*}{ strain } & \multicolumn{5}{|c|}{ Bee pollen } \\
\hline & control & $\begin{array}{l}0.5 \\
\%\end{array}$ & $\begin{array}{c}1 \\
\%\end{array}$ & $\begin{array}{l}1.5 \\
\%\end{array}$ & $\begin{array}{r}2 \\
\%\end{array}$ \\
\hline Lb. del. ssp. bulgaricus (EMCC 1102) & - & & & & \\
\hline S. thermophilus(EMCC 1102) & & & & & \\
\hline St. aureus (ATCC 6538) & & 0.2 & 0.4 & 0.6 & 0.8 \\
\hline B. cereus (ATCC 9639) & & & & & \\
\hline S. typhimurium(ACCT 25566) & & 0.3 & 0.5 & 0.9 & 1 \\
\hline E. coli $(\mathrm{ACCT} 8739)$ & & 0.3 & 0.8 & 1 & 1.2 \\
\hline
\end{tabular}

*Means of triplicates. Means followed by the same superscript are not significantly different, $P<0.05$.

$\mathrm{pH}$ value of White cheeses made with the addition of $0.5,1,1.5$ and $2 \%$ pollen bee were significantly lower than the control treatment at zero time of repining period $(P<0.05$ (Figure 3$) . \mathrm{pH}$ values increased after 45 days of repining period, which might be attributed to the fermentation of lactose by starter cultures (Faion et al 2015).Najgebauer-Lejko et al., (2011) who reported that the tea polyphenols were of a positive effect on yoghurt acidity. Similarly, the acidity produced from starter cultures with apple polyphenolic extracts in yoghurt was also observed by SunWaterhouse et al., (2012) and Rashidinejad et al., (2013).

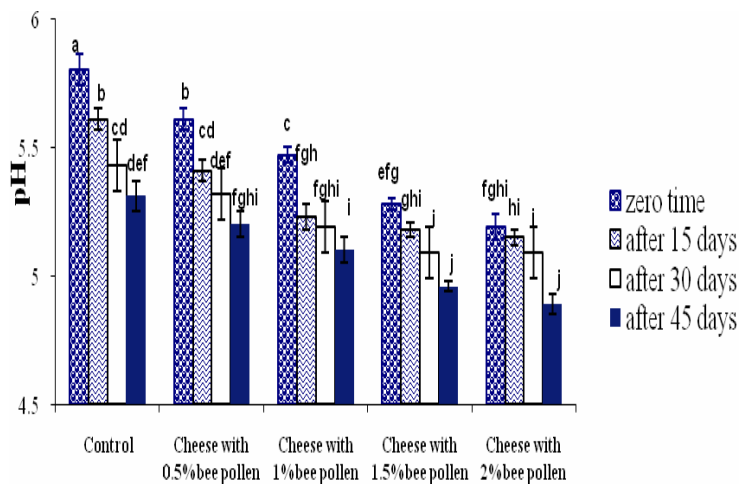

Figure 3. Changes in $\mathrm{pH}$ of White cheese during ripening period. Error bars give the standard deviation, histograms labeled with different letters are significantly at $P<0.05$ (Averages of three replicates).
Yield of cheese (Figure 4) increased from 22.1 to $24.6 \%$ as the level of bee pollen increased from 0.5 to $2 \%$ at zero time. This might be due to the addition of bee pollen, which is of high dry matter. Also, the addition of cow milk to camel milk improved the cheese yield as indicated with the control treatment, when compared with cheese yield camel milk found by Mehaia and Qassim, (1993).It was also observed that the yield of cheeses decreased during the repining period.

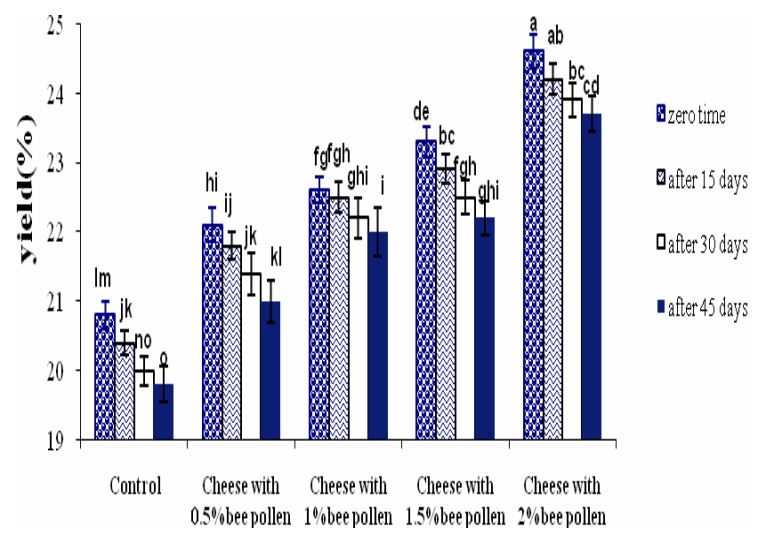

Figure 4. Changes in yield (\%) of White cheese during ripening period. Error bars give the standard deviation, histograms labeled with different letters are significantly at $\boldsymbol{P}<0.05$ (Averages of three replicates).

Statistical analysis (Figure 5) shows that the bee pollen is of a significantly positive effect $(P<0.05)$ on the total solids $(\%)$. This might be due to the reduction of entrapped water in protein networks as a result of hydrophobic interaction between polyphenols and milk proteins, during the coagulation of cheese curd (Han et al., 2011). Also, the changes in the total solids of the samples were similar to those in the protein (Figure 6) and fat (Figure 7) and salt (\%)(Figure 8), which did not change during the ripening period.

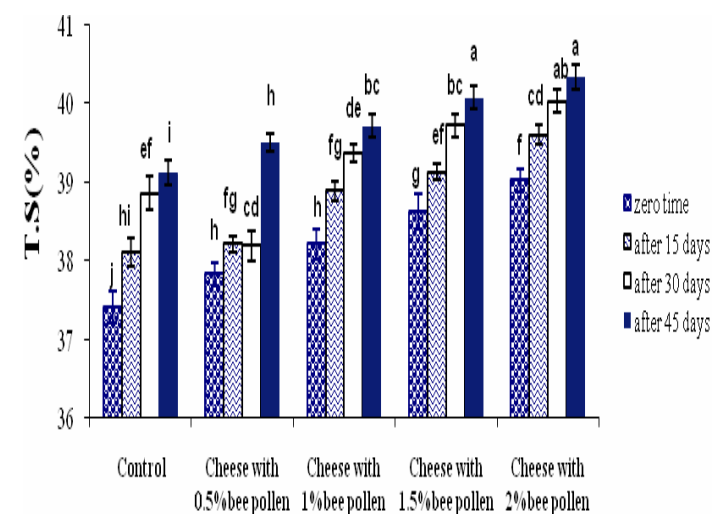

Figure 5. Changes in T.S. (\%) of White cheese during ripening period. Error bars give the standard deviation, histograms labeled with different letters are significantly at $P<0.05$ (Averages of three replicates). 


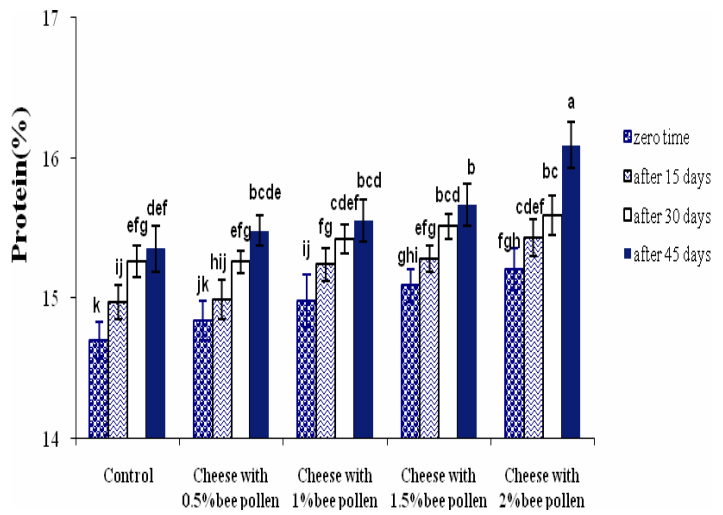

Figure 6. Changes in protein (\%) of White cheese during ripening period. Error bars give the standard deviation, histograms labeled with different letters are significantly at $\boldsymbol{P}<\mathbf{0 . 0 5}$ (Averages of three replicates).

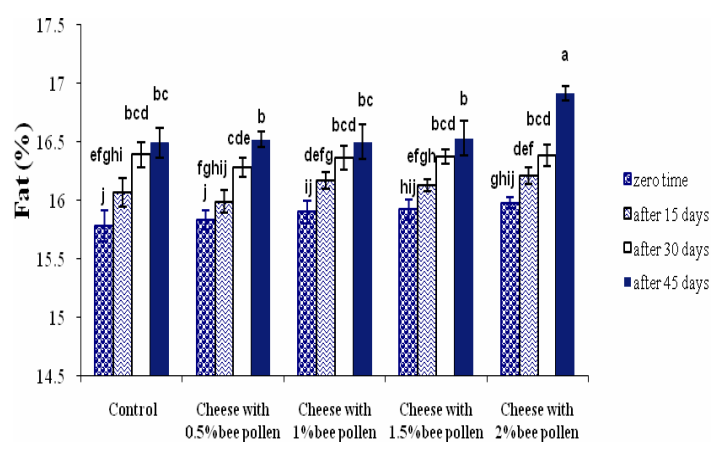

Figure 7. Changes in fat (\%) of White cheese during ripening period. Error bars give the standard deviation, histograms labeled with different letters are significantly at $\boldsymbol{P}<0.05$ (Averages of three replicates).

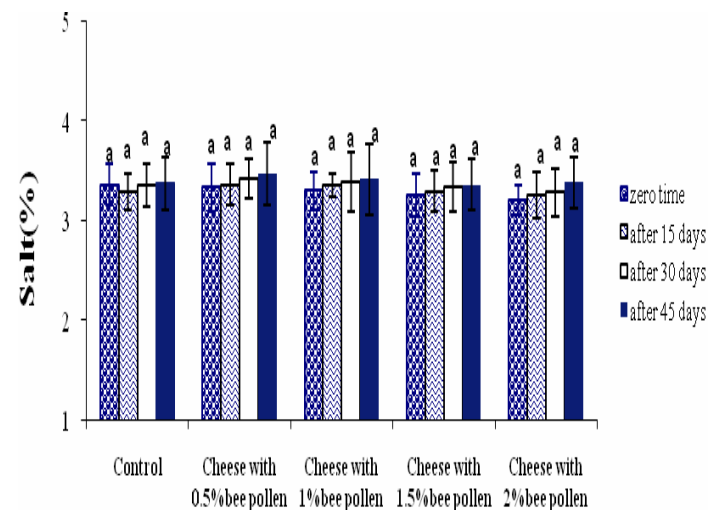

Figure 8. Changes in salt (\%) of White cheese during ripening period. Error bars give the standard deviation, histograms labeled with different letters are significantly at $P<0.05$ (Averages of three replicates).

Regarding the sensory attributes, the addition of bee pollen effected significantly the body and texture, appearance, odour and flavour of the White cheeses due to the concentration of bee pollen(Figures 9 and 10). For example, the resultant cheeses with 1.5 and $2 \%$ pollen bee characterized with the lowest scores for odour appearance, body and texture and flavour, while the addition of 0.5 and $1 \%$ bee pollen were of the highest scores for sensory properties of White cheeses. Faion et al., (2015) found that addition $0.2 \mathrm{wt}$ \% of mate extract affected flavour, texture and acceptance of Prato cheese , which was of a bitter flavour after 45 days. Also, Sharma et al., (2011) obtained on acceptable cheese with $20 \%$ broccoli powder after freeze dried as a source of polyphenolics.

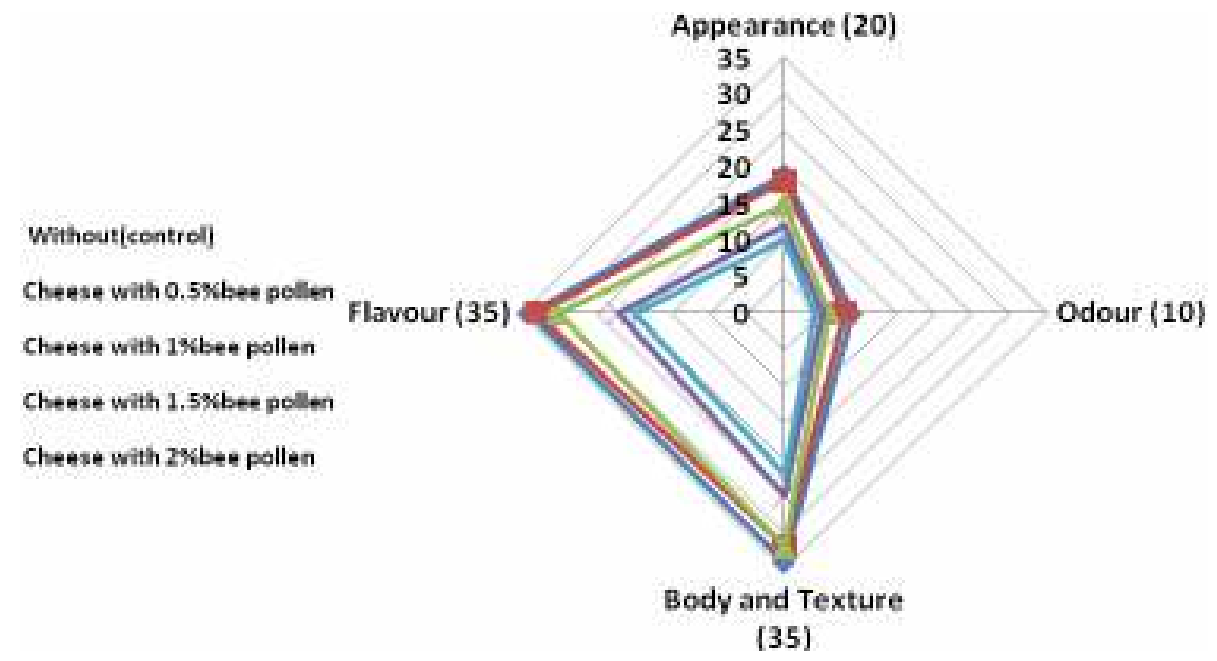

Figure 9. Sensory results for of White cheese at zero time. Error bars give the standard deviation, histograms labeled with different letters are significantly at $P<0.05$ (Averages of three replicates). 


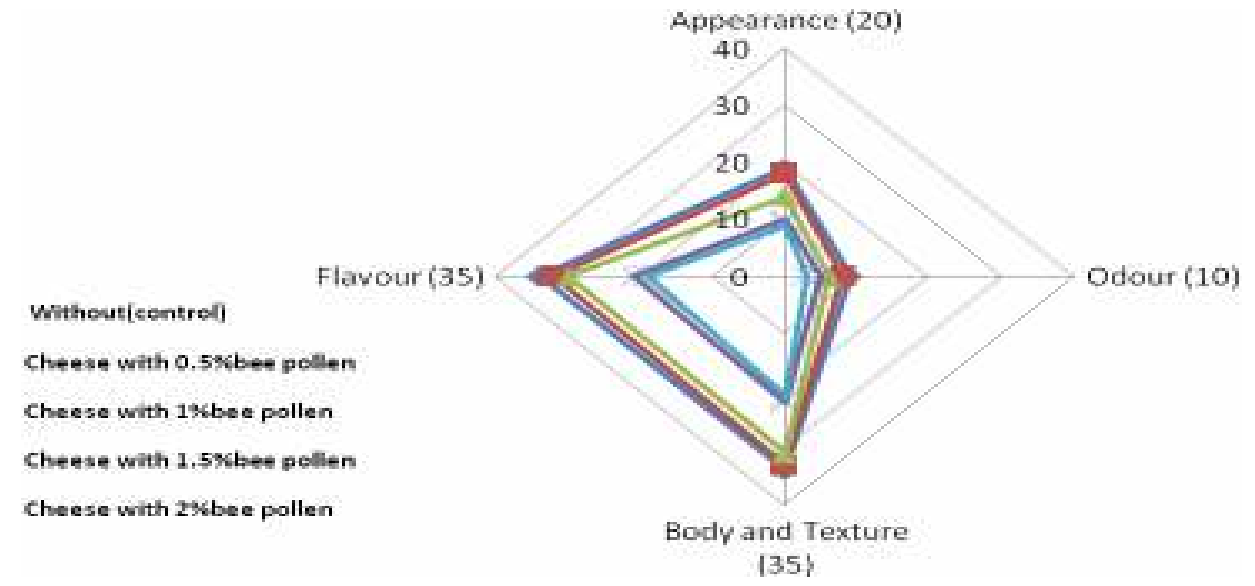

Figure 10. Sensory results for of White cheese after 45 days of ripening period. Error bars give the standard deviation, histograms labeled with different letters are significantly at $\boldsymbol{P}<0.05$ (Averages of three replicates).

\section{CONCLUSION}

It could be concluded that by the addition of bee pollen to white cheese made from camel milk and cow milk mixture up to $1 \%$ was positive effect on the level of bioactive behavior as indicated by the total phenolic compounds, antibacterial and antioxidant activities, and did not have effect on the sensory attributes.

\section{REFERENCES}

Abd Elhamid A. M., and Elbayoumi M. M.,(2017). Effect of Heat Treatment and Fermentation on Bioactive Behavior in Yoghurt Made from Camel Milk. American Journal of Food Science and Technology, 5(3): 109-116. doi: 10.12691/ajfst-5-3-6.

Abou-Donia S. A. (2008). Origin, history and manufacturing process of Egyptian dairy products: an overview. Alexandria Journal of Food Science and Technology. $5: 51-62$.

AOAC, 2000. Official Methods of Analysis, $17^{\text {th }}$ edn, pp 21447. Washington, DC, USA: Association of Official Agricultural Chemists.

Bodyfelt F. W., J. Tobias and G. M. Trout, 1988. The Sensory Evaluation of Dairy Products. London: Van Nostrand Reinhold.

Bogdanov S.,2012. Pollen: Collection, harvest, composition, quality. The bee pollen book (pp. 1-13) http://www. bee- hexagon.net.

Bonvehí S. J., Torrent S. ó, M. and Lorent,C. E. (2001). Evaluation of polyphenolic and flavonoids compounds in honeybee-collected pollen produced in Spain. Journal of Agricultural and Food Chemistry, Washington, 49 : (4) 1848-1853.

Collins, C. H., P. M. Lyne, and J. M. Grange, 1995.Collins and Lyne's microbiological methods. Butterworth Heinemann, Oxford.

De Arruda V.A.S., A.A.S. Pereira, A.S Freitas, O.M. Barth and L.B. Almeida-Muradian, 2013. Dried bee pollen: B complex vitamins, physicochemical and botanical composition, Journal of Food Composition and Analysis, 29: 100-105.
Elayan, A.A., A.M.E. Sulieman and F.A. Saleh, (2008). The hypocholesterolemic effect of Gariss and Gariss containing bifidobacteria in rats fed on a cholesterolenriched diet. Asian J. Biochem., 3: 43-47.

Erkmen, O., Özcan, M.M. (2008): Antimicrobial Effects of Turkish Propolis, Pollen, and Laurel on Spoilage and Pathogenic Food-Related Microorganisms. Journal of Medicinal Food 11, 587-592. doi: dx.doi.org/ 10.1089 / jmf.2007.0038.

Faion A. M, Beal P., Ril F. T., Cichoski A. J., Cansian R. L., Valduga A. T., de Oliveira D. and Valduga E. (2015). Influence of the addition of natural antioxidant from mate leaves (Ilex paraguariensis St. Hill) on the chemical, microbiological and sensory characteristics of different formulations of Prato cheese. J Food Sci Technol :52(3):1516-1524.

Giroux H. J., De Grandpré G., Fustier P., Champagne C. P., St-Gelais D., Lacroix M. and Britten M.(2013). Production and characterization of Cheddar-type cheese enriched with green tea extract. Dairy Sci. \& Technol. 93:241-254.

Han J., M. Britten, D. St-Gelais, C.P. Champagne, P. Fustier, S. Salmieri and M. Lacroix,2011a. Effect of polyphenolic ingredients on physical characteristics of cheese. Food Research International, 44:494- 497.

Han J., M. Britten, D. St-Gelais, C.P. Champagne, P. Fustier, S. Salmieri and M. Lacroix,2011b. Polyphenolic compounds as functional ingredients in cheese. Food Chemistry, 124:1589-1594.

Han L., X. Liu, N. Yang, J. Li, B. Cai and S. Cheng, 2012. Simultaneous chromatographic fingerprinting and quantitative analysis of flavonoids in Pollen Typhae by high-performance capillary electrophoresis, Acta Pharmaceutica Sinica, B 2 (6): 602-609.

Han, X., Shen, T., \& Lou, H. (2007). Dietary polyphenols and their biological significance. International Journal of Molecular Science, 8, 950-988.

James C. S. 1995. Analytical Chemistry of Food. Glasgow, UK: Blackie Academic \&Professional.

Khan AA, Alzohairy MA, (2011) Hepatoprotective effects of camel milk against CCl4-induced hepatotoxicity in rats. Asian J Biochem, 6: 171-180. 
Linskens H. F. and W. Jorde, 1997. Pollen as food and medicine e a review. Economic Botany, 51(1): 78-86.

Lundgren, J. G., and Wiedenmann, R. N. (2004). Nutritional suitability of corn pollen for the predator Coleomegilla maculata (Coleoptera: Coccinellidae). Journal of Insect Physiology, 50, 567-575.

Majeed NA(2005). Corrective effect of milk of camel on some cancer biomarkers in blood of rats intoxicated with aflatoxin B. J Saudi Chem Soc, 9: 253-264.

Malerbo-Souza D. T. 2011. The corn pollen as a food source for honeybees. Acta Scientiarum Agronomy, 33: 701-704.

Marshall R. T. 1992. Chemical and Physical Methods, PP 433-529. Standard Methods for the Examination of Dairy Product, 16th edn. Washington, DC: American Public Health Association.

Mehaia, M.A. and B. Qassim, (1993). Composiotion, yield and organoleptic evaluation of fresh Domiati cheese made from a mixture of camel and cow milk. Australian Journal of Dairy Tech., 48: 74-77.

Najgebauer-Lejko, D., Sady, M., Grega, T. \& Walczycka, M. (2011). The impact of tea supplementation on microflora, $\mathrm{pH}$ and antioxidant capacity of yoghurt. International Dairy Journal, 21, 568-574.

O'Connell J.E. and P.F. Fox (2001) Significance and applications of phenolic compounds in the production and quality of milk and dairy products: a review. International Dairy Journal, 11:103-120.

Oszmianski, J., Ramos, T., \& Bourzeix, M. (1988). Fractionation of phenolic compounds in red wine. American Journal of Enology and Viticulture, 39, 259-262.

Oyaizu, M. (1986). Antioxidative activities of browning reaction prepared from glucosamine. Jpn. J. Nutr. 44:307.

Rashidinejad A., Birch E. J., Sun-Waterhouse D. and Everett W. D.(2013). Effects of catechin on the phenolic content and antioxidant properties of lowfat cheese. International Journal of Food Science and Technology 2013, 48, 2448-2455.
SAS (2000) SAS User's Guide. Version 4.Cary, NC, SAS Institute, USA.

Saura-Calixto, F. 2011. Dietary fiber as a carrier of antioxidants: An essential physiological function. J.Agric. Food Chem. 59, 43-49.

Sharma K. D. , Stähler K. , Smith B. and Melton L.(2011). Antioxidant capacity, polyphenolics and pigments of broccoli-cheese powder blends. J Food Sci Technol, 48(4):510-514.

Singleton, V.L., Orthofer, R. \& Lamuela-Ravent_os, R.M. (1999). Analysis of total phenols and other oxidation substrates and antioxidants by means of FolinCiocalteu reagent. In: Methods in Enzymology: Oxidants and Antioxidants Part A, Vol. 299 (edited by P. Lester). Pp. 152-178. Waltham, MA. USA: Academic Press.

Sipahioglu O., V. B. Alvarez and C-L. Solano,1999. Structure, physic-chemical and sensory properties of feta cheese made with tapioca starch and lecithin as fat mimetics. International Dairy Journal. 9:783-789.

Sun-Waterhouse, D., Zhou, J. \& Wadhwa, S. (2012). Effects of adding apple polyphenols before and after fermentation on the properties of drinking yoghurt. Food and Bioprocess Technology, 5, 2674-2686.

Yerlikaya O(2014). Effect of bee pollen supplement on antimicrobial, chemical, rheological, sensorial properties and probiotic viability of fermented milk beverages .Fermented milk beverages, Mljekarstvo 64 (4), 268-279.

Zhu C., D. Xiaoyan and S. Feng 2008. Evaluation of the antioxidant activity of Chinese Hickory (Caryacathayensis) kernel ethanol extraction. African Journal of Biotechnology, 7: 2169-2173.

Žilić S., Vančetović J, Marijana Janković M. and Maksimović V.(2014).Chemical composition, bioactive compounds, antioxidant capacity and stability of floral maize (Zea mays L.) pollen. Journal of Functional Foods, 10: 65-74.

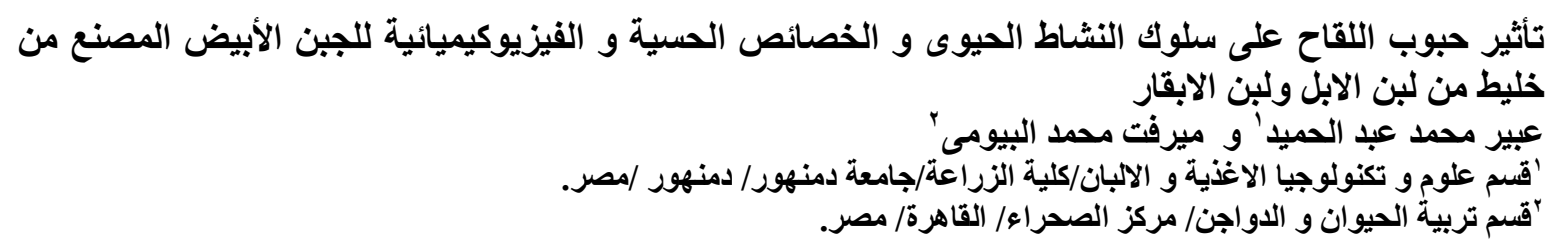

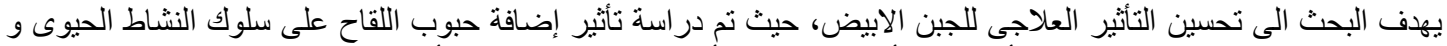

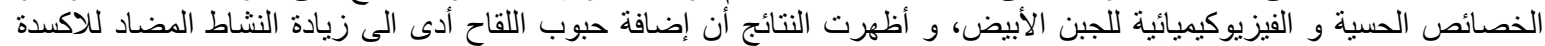

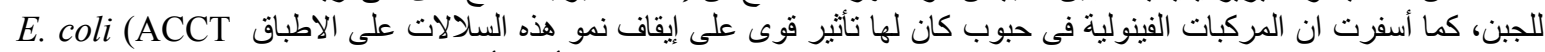
(A 8739), St. aureus (ATCC 6538) S. typhimurium (ACCT 25566).

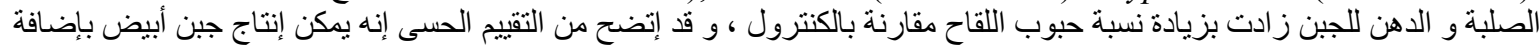

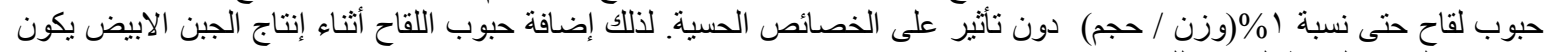

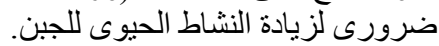

